\title{
UJI EFEKTIFITAS EKSTRAK BAWANG PUTIH (ALLIUM SATIVUM) SEBAGAI INSEKTISIDA TERHADAP KUTU RAMBUT (PEDICULUS CAPITIS)
}

\author{
Ardhita Prilly Pritacindy \\ Supriyadi \\ Agung Kurniawan \\ Universitas Negeri Malang \\ e-mail: ardhita.cindy@gmail.com
}

\begin{abstract}
Hair lice are small parasites that live by sucking blood in humans. Almost all patients consider the hair tick is a common thing, but if the hair louse is not treated immediately will cause the emergence of Relapsing Fever disease caused by infection in the scalp of the patient. The purpose of this study is to determine the effectiveness of garlic extract with concentrations of $4 \%$, $6 \%$, and $8 \%$ as an insecticide against hair lice. The research method used is true experimental or real experiment using sample of each group (4\%, 6\%, and 8\%) need 10 lice hair with 3 times experiment so that require 120 samples of hair louse. Data analysis was done using One Way Anova test with result F count 806.493> F table 2.87. Then there is the difference in the time to kill a hair louse. While based on Post Hoc follow-up test obtained the probability value is $<0.05$ that can be said to have significant differences. The conclusion of hypothesis testing is garlic extract with concentration 4\%, 6\%, and 8\% effectiveness as insecticide to hair louse. Suggestions that can be submitted in this study that requires further research to determine the right concentration when it will be applied to the scalp and need further research to determine the form of a good preparation for insecticides.
\end{abstract}

Key words : Head Lice, Garlic, Insecticide

\begin{abstract}
Abstrak: Kutu rambut merupakan parasit kecil yang hidup dengan cara menghisap darah pada manusia. Hampir semua penderita menganggap kutu rambut adalah hal yang biasa, padahal apabila penderita kutu rambut tidak segera ditangani akan menyebabkan timbulnya penyakit Relapsing Fever yang disebabkan adanya infeksi pada kulit kepala penderita.Tujuan dilakukan penelitian ini yaitu untuk mengetahui efektifitas ekstrak bawang putih dengan konsentrasi 4\%, $6 \%$, dan $8 \%$ sebagai insektisida terhadap kutu rambut. Metode penelitian yang digunakan adalah metode true experimental atau eksperimen sungguhan dengan menggunakan sampel setiap kelompok $(4 \%, 6 \%$, dan 8\%) membutuhkan 10 kutu rambut dengan 3 kali percobaan sehingga memerlukan 120 sampel kutu rambut. Analisa data dilakukan menggunakan uji One Way Anova dengan hasil F hitung 806,493 > F tabel 2,87. Maka terdapat perbedaan waktu bunuh kutu rambut. Sedangkan berdasarkan uji lanjutan Post Hoc didapatkan nilai probabilitas yaitu $0,00<0.05$ sehingga dapat dikatakan memiliki perbedaan yang signifikan. Kesimpulan dari pengujian hipotesis tersebut adalah ekstrak bawang putih dengan konsentrasi 4\%, 6\%, dan $8 \%$ efektiv sebagai insektisida terhadap kutu rambut. Saran yang dapat disampaikan pada penelitian ini yaitu memerlukan penelitian lanjutan untuk menentukan konsentrasi yang tepat apabila akan diaplikasikan ke kulit kepala dan perlu penelitian lanjutan untuk mengetahui bentuk sediaan yang baik untuk insektisida.
\end{abstract}

Kata Kunci : Kutu Rambut, Bawang Putih, Insektisida

Kutu rambut (pediculus capitis) merupakan parasit kecil yang hidup dengan cara menghisap darah pada bagian kepala manusia (Ansyah, 2013).

Di Indonesia tidak terdapat data mengenai penderita kutu rambut karena hampir semua penderita menganggap kutu rambut adalah hal yang biasa, padahal apabila tidak segera ditangani akan menyebabkan timbulnya penyakit 
relapsing fever yang disebabkan karena adanya infeksi pada kulit kepala penderita (Public School NSW, 2013). Keberadaan kutu rambut di kepala juga dapat menyebabkan kekurangan zat besi dan anemia. Pada anak yang terinfeksi kutu rambut dewasa sekitar 30 ekor dapat kehilangan darah sekitar $0,008 \mathrm{ml}$ perhari (Nindia, 2016).

Penderita kutu rambut (pediculus capitis) biasanya anak-anak pra-sekolah karena pada usia tersebut kurang mampu menjaga kebersihan dirinya secara mandiri. Sekitar $63 \%$ remaja di atas usia 15 tahun memiliki kemungkinan terjangkit kutu rambut karena banyak remaja yang masih belum mengetahui bahaya yang diakibatkan oleh kutu rambut (Fadilha, 2015).

Penanggulangan kutu rambut dapat dilakukan dengan dua cara yaitu secara mekanis dan secara kimiawi. Secara mekanis dapat dilakukan dengan cara menjaga kebersihan kepala, sedangkan kimiawi dapat dilakukan dengan cara menggunakan obat pembasmi kutu rambut yang beredar di pasaran (Alatas, 2013). Penggunaan insektisida kimia diyakini dapat membasmi vektor penyakit secara cepat namun memiliki dampak buruk bagi kesehatan manusia dan lingkungan apabila digunakan secara berlebihan. Menurut WHO (World Health Organization) sebanyak 44.000-2.000.000 orang setiap tahunnya mengalami keracunan akibat insektisida kimia (Yenie, 2013).

Banyaknya dampak negatif akibat insektisida kimia membuat pemerintah mengeluarkan PERMENKES No. 374/MENKES/PER/III/2010 tentang pengendalian vektor penyakit yang di dalamnya terdapat standar dan syarat penggunaan insektisida (Kemenkes, 2012).

Insektisida kimia memiliki cara kerja dan kemampuan untuk mematikan hama sesuai dengan sifat bahan kimia dari insektisida tersebut. Insektisida tergolong menjadi.

1. Racun perut atau lambung
Merupakan bahan beracun yang dapat merusak sistem pencernaan serangga.

2. Racun kontak

Merupakan bahan beracun yang dapat membunuh atau menganggu perkembangbiakan serangga, jika bahan beracun tersebut mengenai tubuh serangga.

3. Racun nafas

Merupakan bahan beracun yang biasanya berbentuk gas atau bahan lain yang mudah menguap jika terhisap oleh sistem pernafasan serangga tersebut.

4. Racun saraf

Merupakan insektisida yang cara

kerjanya menganggu sistem saraf serangga.

5. Racun protoplasmik

Merupakan racun yang bekerja dengan cara merusak protein dalam sel tubuh serangga (Hudayya, 2012).

Berdasarkan tingginya dampak negatif dari penggunaan insektisida kimia maka diperlukan alternatif pembasmian kutu rambut (pediculus capitis) menggunakan insektisida alami. Insektisida alami yang dapat digunakan untuk membasmi kutu rambut salah satunya yaitu tanaman bawang putih (allium sativum) (Asmaliyah, 2012).

Bawang putih atau garlic berasal dari bahasa inggris kuno yang artinya "gar" yang berarti tombak atau ujung tombak dan "lic" yang berarti umbi atau bakung. Dan memiliki nama latin allium sativum yang berasal dari bahasa caltic yang artinya "all" berarti berbau tidak sedap dan "sativum" berarti tumbuh (Yuniastuti, 2006). Bawang putih adalah herbal semusim berumpun yang mempunyai ketinggian sekitar $60 \mathrm{~cm}$. Memiliki batang semu berwarna hijau dan bagian bawahnya bersiung-siung bergabung menjadi umbi besar berwarna putih (Khairani, 2014).

Bawang putih memiliki kandungan berbagai zat yang menguntungkan bagi manusia, beberapa zat yang terkandung dalam bawang putih terbukti ampuh mengobati berbagai penyakit dan menjaga kesehatan tubuh (Trishadi, 2016). Bawang putih tidak hanya 
memiliki kandungan gizi yang lengkap tetapi juga terdapat kandungan kimia non-gizi yang memiliki manfaat untuk kesehatan sekaligus dapat digunakan sebagai pembasmi vektor penyakit secara alami. Kandungan senyawa kimia yang terdapat pada bawang putih yaitu allixin, adenosin, ajoene, flavonoid,

saponin, tuberholosida, scordinin. Dimana aliixin, saponin, dan flavonoid merupakan bahan kimia yang dapat difungsikan sebagai insektisida terutama dalam membasmi kutu rambut yang aman bagi kesehatan dan lingkungan (Sukma, 2016).

Beberapa sifat aliixin, flavonoid, dan saponin yang berfungsi sebagai insektisida alami pembasmi kutu rambut (pediculus capitis), yaitu:

1. Aliixin

Kandungan kimia dari umbi bawang putih per 100 gram mengandung allixin sebesar 1,5\% (Untari, 2010). Kandungan allixin dapat mencapai $82 \%$ dari keseluruhan kandungan organosulfur yang ada didalam umbi bawang putih (Hernawan, 2003).

Allixin merupakan senyawa yang berperan memberi aroma yang khas pada bawang putih. Allixin mengandung sulfur dengan struktur tidak jenuh yang mudah terurai serta allixin bekerja dengan cara merusak membran sel parasit sehingga parasit tidak dapat berkembang lebih lanjut. Allixin merupakan zat aktif yang mempunyai daya antibiotik cukup ampuh (Hanani, 2013).

\section{Flavonoid}

Flavonoid merupakan senyawa yang berperan sebagai antioksidan yang juga memiliki sifat sebagai racun perut (stomach poisoning), yang bekerja apabila senyawa tersebut masuk dalam tubuh serangga maka akan mengganggu organ pencernaan. Senyawa racun yang bersifat racun akan masuk ke dalam tubuh dan mengalami biotransformasi menghasilkan senyawa yang larut dala bersifat racun akan masuk ke dalam tubuh dan mengalami biotransformasi menghasilkan senyawa yang larut dalam air. Proses metabolisme tersebut membutuhkan energi, semakin banyak racun yang masuk kedalam tubuh serangga mengakibatkan terhambatnya metabolisme sehingga serangga kekurangan energi dan mengalami kematian (Nisma, 2011).

3. Saponin

Saponin merupakan racun yang dapat menghancurkan butir darah atau hemalosis pada darah, bersifat racun pada hewan berdarah dingin dan saponin bersifat racun yang biasa disebut sapotoksin (Rachman, 2015).

Saponin masuk kedalam tubuh vektor penyakit melalui dua cara yaitu melalui sistem pernafasan dan melalui kontak fisik serta bekerja dengan cara menghambat enzim pencernaan sehingga metabolisme vektor penyakit akan terganggu dan mengakibatkan

kematian pada vektor penyakit (Muta'ali, 2015).

Untuk mendapatkan senyawa allixin, saponin, dan flavonoid dapat dilakukan dengan cara ekstraksi menggunakan pelarut etanol dan untuk umur bawang putih yang baik saat dipanen yaitu bekisar 3,5-4 bulan dengan proses pengeringan bersusut sampai sekitar $15 \%$ dari berat awal atau selama 7-10 hari proses penjemuran (Khairani, 2014).

Pemilihan bawang putih yang baik dipengaruhi pada khasiat bawang putih yang ditimbulkan. Bawang putih yang baik memiliki umbi yang berisi dan tidak keriput, berwarna putih bersih, dan pada siung bawang putih masih utuh sehingga lebih terjaga dari kontaminan dan bawang putih yang segar akan lebih sulit saat dikupas dari pada bawang putih yang sudah lama karena bawang putih yang sudah lama akan berkurang ukurannya. Umur bawang putih yang baik untuk dipanen yaitu bekisar antara 3,5-4 bulan dengan proses pengeringan sampai bawang putih bersusut $15 \%$ dari berat awal atau 7-10 hari penjemuran (Khairani, 2014).

\section{METODE}

Penelitian ini menggunakan pendekatan kuantitatif dengan metode 
penelitian yang digunakan adalah metode true experimental atau eksperimen sungguhan dan menggunakan rancangan perbandingan kelompok statis (posttest only control group design). Populasi dalam penelitian ini yaitu kutu rambut manusia dengan sampel sebanyak 10 sapel dengan pengulangan 3 kali percobaan pada 4 kelompok yaitu kelompok kontrol, kelompok perlakuan 4\%, kelompok perlakuan $6 \%$, dan kelompok perlakuan $8 \%$. Sehingga memerlukan total sampel sebanyak 160 sampel kutu rambut.

Data diperoleh berdasrkan lama waktu yang digunakan untuk membasmi kutu rambut (pediculus capitis) dan menjadi indikator efektifitas ekstrak bawang putih (allium sativum) sebagai insektisida terhadap kutu rambut (pediculus capitis).

Tahap pelaksanaan dengan cara menyemprotkan ekstrak bawang putih yang telah ditetapkan pada sampel kelompok perlakuan dan dilakukan pada suhu yang efektif untuk kutu rambut bergerak. Selanjutnya mencatat waktu kematian kutu rambut dengan indikator tidak bergeraknya kutu rambut atau

tidak berpindah tempat dengan menggunakan bantuan milimeterblok.

Metode analisis data dilakukan menggunakan uji oneway ANOVA karena penelitian berupa variabel numerik lebih dari 2 kelompok tidak berpasangan. Teknik analisi data dilakukan dengan tahap melakukan uji normalitas untuk mengetahui apakah data yang digunakan berdistribusi normal, selanjutnya melakukan uji homogenitas untuk mengetahui data yang digunakan bersifat homogen atau tidak. Apabila data yang digunakan memiliki distribusi normal dan bersifat homogen maka dapat langsung dilanjutkan dengan uji oneway ANOVA

\section{HASIL}

Dalam penelitian ini data yang dianalisis yaitu waktu bunuh kutu rambut (pediculus capitis) menggunakan ekstrak bawang putih (allium sativum). Penelitian dilakukan pada ruangan dengan rentang suhu $28,3^{\circ} \mathrm{C}-29,4^{\circ} \mathrm{C}$.

\begin{tabular}{|c|c|c|c|c|}
\hline & \multicolumn{3}{|c|}{ Pengulangan $\left({ }^{\circ} \mathrm{C}\right)$} & \multirow{2}{*}{ MEAN } \\
\hline & I & II & III & \\
\hline Kelompok Kontrol & 28,3 & 28,3 & 28,3 & 28.3 \\
\hline Perlakuan konsentrasi $4 \%$ & 28,9 & 29 & 29,4 & 28.7 \\
\hline Perlakuan konsentrasi $6 \%$ & 28,7 & 28,3 & 29,2 & 28.8 \\
\hline Perlakuan konsentrasi $8 \%$ & 29,2 & 29,7 & 28,5 & 29.3 \\
\hline MEAN & & & & 28,77 \\
\hline $\begin{array}{l}\text { Dari hasil tabel diatas diketahui } \\
\text { suhu rata-rata yang digunakan dalam } \\
\text { penelitian uji efektivitas ekstrak bawang }\end{array}$ & $\begin{array}{l}\text { putih } \\
\text { ram } \\
28,7\end{array}$ & $\begin{array}{r}\text { sativum) } \\
\text { (pec }\end{array}$ & $\begin{array}{l}\text { kutu } \\
\text { US }\end{array}$ & yaitu \\
\hline
\end{tabular}

\section{UJI NORMALITAS}

\begin{tabular}{cc}
\hline & Unstandardized Residual \\
\hline$N$ & 40 \\
Asymp. Sig. & .060 \\
\hline
\end{tabular}

Berdasarkan hasil uji normalitas didapatkan hasil sig. 0,06, dimana hasil tersebut kurang dari 0,05 sehingga data dapat dikatakan berdistribusi normal dan dapat dilakukan uji One Way Anova. 


\begin{tabular}{cl}
\hline \multicolumn{1}{c}{ Levene Statistic } & \multicolumn{1}{c}{ Sig. } \\
\hline 16,505 & .000 \\
\hline Berdasarkan hasil uji homogenitas & tersebut memiliki varian yang homogen \\
tersebut, didapatkan hasil levene statistic & sehingga dapat dilakukan uji lanjutan \\
16,505. Dimana hasil tersebut lebih dari & yaitu uji One Way Anova. \\
0,05. Sehingga dapat dikatakan data &
\end{tabular}

0,05 . Sehingga dapat dikatakan data

UJI ONEWAY ANOVA

\begin{tabular}{lll}
\hline Uji Anova Oneway & $F$ & Sig. \\
\cline { 2 - 3 } & 806,493 & .000
\end{tabular}

Dari data tersebut $\mathrm{F}$ hitung sebesar 806,493, sedangkan F tabel sebesar 2,87. Karena $\mathrm{F}$ hitung lebih dari $\mathrm{F}$ tabel maka dapat dikatakan Ho ditolak. Sehingga dapat disimpulkan bahwa terdapat perbedaan rata-rata waktu kematian kutu rambut (pediculus capitis) dari perlakuan $4 \%, 6 \%$, dan $8 \%$.
Berdasarkan nilai probabilitas yang tercantum pada kolom sig. diperoleh nilai 0,000 , dimana nilai tersebut kurang dari 0,05 sehingga dapat dikatakan Ho ditolak atau terdapat perbedaan efektifitas ekstrak bawang putih berdasarkan konsentrasi bawang putih.

\section{UJI LANJUTAN POST HOC}

\begin{tabular}{|c|c|c|c|c|}
\hline & & Mean Difference & Std. Erro & Sig. \\
\hline \multirow[t]{3}{*}{1} & 2 & 8,53900 & 0,21824 & .000 \\
\hline & 3 & 8,83600 & 0,21824 & .000 \\
\hline & 4 & 8,91100 & 0,21824 & .000 \\
\hline \multirow[t]{3}{*}{2} & 1 & $-8,52900$ & 0,21824 & .000 \\
\hline & 3 & 0,30700 & 0,21824 & .168 \\
\hline & 4 & 0,38200 & 0,21824 & .089 \\
\hline \multirow[t]{3}{*}{3} & 1 & $-8,83600$ & 0,21824 & .000 \\
\hline & 2 & $-0,30700$ & 0,21824 & .168 \\
\hline & 4 & 0,07500 & 0,21824 & .733 \\
\hline \multirow[t]{3}{*}{4} & 1 & $-8,91100$ & 0,21824 & .000 \\
\hline & 2 & $-0,38200$ & 0,21824 & .089 \\
\hline & 3 & $-0,07500$ & 0,21824 & .733 \\
\hline
\end{tabular}

Keterangan:

$1=$ kelompok kontrol,

$2=$ kelompok perlakuan $4 \%$

$3=$ kelompok perlakuan $6 \%$

$4=$ kelompok perlakuan $8 \%$

Kelompok kontrol memiliki perbedaan dengan kelompok perlakuan yang signifikan dengan kelompok perlakuan $4 \%, 6 \%$, dan $8 \%$ dengan menggunakan uji bonferroni. Hal ini dikarenakan kelompok kontrol memiliki nilai probabilitas kurang dari 0,05 , sehingga dapat dikatakan ekstrak bawang putih memiliki pengaruh yang signifikan antara kelompok kontrol dengan kelompok perlakuan pada konsentrasi $4 \%, 6 \%$, dan $8 \%$. 


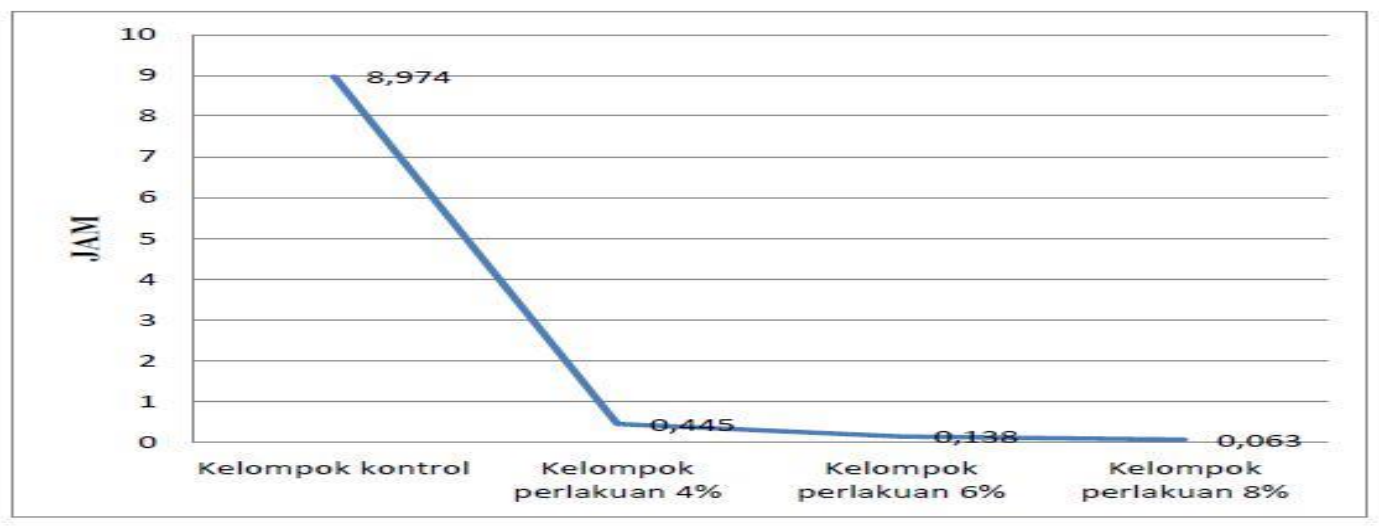

Dari hasil diagram tersebut menunjukan sebaran data setiap kelompok. Dari hasil grafik tersebut dapat dilihat rata - rata waktu bunuh kutu rambut (pediculus capitis) dengan tingkat konsentrasi yang semakin tinggi maka akan semakin cepat waktu bunuh kutu rambut seperti halnyapada konsentrasi terendah $4 \%$ membutuhkan waktu bunuh selama 0,4450 jam , konsentrasi $6 \%$ membutuhkan waktu bunuh selama 0,1380 jam, dan konsentrasi tertinggi $8 \%$ membutuhkan waktu bunuh selama 0,0630 jam. Dan dapat disimpulkan bahwa pada konsentrasi $8 \%$ ekstrak bawang putih (allium sativum) lebih efektiv sebagai insektisida terhadap kutu rambut (pediculus capitis) karena membutuhkan waktu bunuh yang lebih cepat sehingga semakin tinggi tingkat konsentrasi yang digunakan maka akan semakin cepat waktu bunuh yang dibutuhkan untuk kutu rambut (pediculus capitis).

\section{PEMBAHASAN}

Dalam penelitian uji efektivitas ekstrak bawang putih (allium sativum), sampel yang didapatkan berasal dari 3 anak dengan usia $7-9$ tahun. Berdasarkan penelitian yang dilakukan Rumampuk (2014), anak yang terinfestasi kutu kepala (pediculus capitis) rata - rata berusia 7 - 12 tahun dengan gejala yang dirasakan yaitu rasa gatal pada kulit kepala dan munculnya iritasi pada kulit kepala.

Kutu rambut (pediculus capitis) merupakan kutu penghisap darah (ordo anoplura) dan hidup pada kulit kepala manusia. Kutu rambut (pediculus capitis) berada pada rambut kepala terutama pada bagian tengkuk, telinga, dan siklus hidup kutu rambut dihabiskan pada kepala manusia. Siklus hidup kutu rambut (pediculus capitis) dimulai

dengan peletakan telur yang ditempelkan pada rambut kepala. Setelah 3-4 hari telur kutu rambut akan menetas menjadi nimfa, nimfa mengalami 3 kali pengupasan kulit dan menjadi kutu dewasa. 24 jam sesudah terjadi perkawinan kutu jantan dan kutu betina, kutu betina akan meletakkan telur sebanyak $7-10$ telur (nits) setiap hari. Lama hidup kutu rambut (pediculus capitis) dapat mencapai 30 hari dan hidup dengan menghisap darah manusia. Kutu rambut (pediculus capitis) tidak dapat hidup tanpa darah dalam waktu 15-20 jam. Nimfa dan kutu dewasa menghisap darah dan dalam proses ini penderita akan merasa gatal sehingga menggaruk kulit kepala. Kaki kutu rambut (pediculus capitis) didesain untuk mencengkram rambut dan dapat berjalan 2-3 cm permenit. Kutu rambut (pediculus capitis) hanya dapat hidup 1-2 hari diluar kulit kepala sedangkan telurnya dapat bertahan hingga 10 hari (Rumampuk,2014).

Berdasarkan hasil penelitian didapatkan data yang menunjukan

bahwa pada kelompok kontrol memerlukan waktu bunuh rata - rata 8,9740 jam. Dengan kata lain, berdasarkan hasil penelitian yang dilakukan, kutu rambut (pediculus 
capitis) tidak dapat hidup tanpa darah < 15 jam. Sedangkan untuk kelompok perlakuan dengan konsentrasi 4\% menghasilkan rata - rata waktu bunuh 0,4450 jam. Untuk kelompok perlakuan dengan konsentrasi $6 \%$ menghasilkan waktu bunuh rata - rata 0,1380. Dan untuk kelompok perlakuan dengan konsentrasi $8 \%$ menghasilkan waktu bunuh 0,0630. Berdasarkan hasil rata rata waktu bunuh kutu rambut (pediculus capitis) didapatkan hasil $\mathrm{F}$ hitung sebesar 806,493 dengan $\mathrm{F}$ tabel sebesar 2.87. maka dapat disimpulkan $\mathrm{F}$ hitung $>\mathrm{F}$ tabel yang berarti terdapat perbedaan waktu bunuh kutu rambut

(pediculus capitis). Sedangkan berdasarkan uji lanjutan Post Hoc didapatkan hasil bahwa kelompok kontrol memiliki perbedaan yang signifikan dengan kelompok perlakuan dengan konsentrasi $4 \%, 6 \%$, dan $8 \%$. Dari hasil uji Post Hoc didapatkan nilai probabilitas yaitu $0,000<0,05$, sehingga dapat dikatakan memiliki perbedaan yang signifikan.

Pada penelitian yang dilakukan sebelumnya oleh Hanani (2014), larutan bawang putih sebagai insektisida nabati untuk membunuh larva nyamuk aedes aegypty dengan konsentrasi 25\%, 50\%, $75 \%$, dan $100 \%$. Berdasarkan hasil uji statistik yang dilakukan terdapat perbedaan daya bunuh larutan bawang putih dengan konsentrasi 25\%, 50\%, $75 \%$, dan $100 \%$ dalam membunuh larva nyamuk aedes aegypti. Sedangkan menurut penelitian yang dilakukan Burton (2013), rata - rata jumlah larva nyamuk culex sp. yang mati pada kelompok yang diberikan ekstrak bawang putih $4 \%$ adalah 31 , pada $5 \%$ adalah 45,2 , pada $6 \%$ adalah 50,6 , pada $7 \%$ adalah 57,8 , dan pada $8 \%$ adalah 78,4. Berdasarkan hasil uji statistika menunjukkan terdapat perbedaan yang bermakna. Artinya, ekstrak bawang putih mempunyai efektivitas terhadap larva.

Menurut Nindia (2016) menjelaskan masa inkubasi kutu rambut (pediculus capitis) membutuhkan iklim lembab dan hangat. Suhu yang optimal untuk perkembangan kutu rambut yaitu antara $28^{\circ} \mathrm{C}-32^{\circ} \mathrm{C}$. Kutu rambut (pediculus capitis) dapat bertahan selama 10 hari pada suhu $5^{\circ} \mathrm{C}$ tanpa makan, dapat menghisap darah untuk waktu yang lama, mati pada suhu $40^{\circ} \mathrm{C}$ dan dapat memusnahkan telur kutu rambut pada suhu $60^{\circ} \mathrm{C}$ dalam waktu 15 30 menit.

Berdasarkan Tabel data waktu bunuh kelompok kontrol kutu rambut (pediculus capitis) menunjukan bahwa hasil suhu perlakuan uji efektivitas ekstrak bawang putih (allium sativum) pada kelompok kontrol menghasilkan mean sebesar $28,3^{\circ} \mathrm{C}$, kelompok perlakuan dengan konsentrasi $4 \%$ sebesar $28,7^{\circ} \mathrm{C}$, kelompok perlakuan dengan konsentrasi $6 \%$ sebesar $28,8^{\circ} \mathrm{C}$, dan kelompok perlakuan dengan konsentrasi $8 \%$ sebesar $29,3^{\circ} \mathrm{C}$. Hasil tersebut sesuai dengan suhu optimal perkembangan kutu rambut (pediculus capitis). Sehingga suhu yang dilakukan dalam penelitian tidak mempengaruhi waktu bunuh kutu rambut (pediculus capitis).

Pada penelitian yang telah dilakukan Tigauw (2015), ekstrak bawang putih dapat dimanfaatkan sebagai bioinsektisida dengan ditandai adanya pengaruh yang nyata terhadap mortalitas kutu daun. Dimana kutu daun (myzus persicae Sulz) memiliki klasifikasi yang sama dengan kutu rambut (pediculsu capitis) yaitu memiliki kingdom animalia, phylum

arthropoda, dan kelas insekta. Konsentrasi ekstrak bawang putih yang efektif dalam mengendalikan populasi kutu daun (M. Persicae) tertinggi terdapat pada konsentrasi $60 \%$ dengan mortalitas sebanyak 72,33\%, diikuti dengan konsentrasi $45 \%$ dengan mortalitas sebanyak 54,00\%, dan terendah berada pada konsentrasi $0 \%$ (kontrol) dengan mortalitas sebanyak $34,67 \%$. Hasil pengujian terhadap mortalitas kutu daun yang paling efektif sebagai bioinsektisida adalah ekstrak bawang putih pada konsentrasi 60\% dengan rata - rata mortalitas sebanyak $72,33 \%$. 
Ditinjau dari hasil penelitian yang telah dilakukan dapat diketahui bahwa ekstrak bawang putih (allium sativum) sangat efektif sebagai insektisida terhadap kutu rambut (pediculus capitis). Efek ekstrak bawang putih (allium sativum) terhadap kutu rambut (pediculus capitis) pada konsentrasi terendah $4 \%$ membutuhkan waktu bunuh selama 0,4450 jam, konsentrasi $6 \%$ membutuhkan waktu bunuh selama 0,1380 jam, dan konsentrasi tertinggi $8 \%$ membutuhkan waktu bunuh selama 0,0630 jam. Berdasarkan Susilo (2013) efektivitas adalah suatu ukuran yang menyatakan seberapa jauh target (kualitas, kuantitas, dan waktu) telah tercapai. Sehingga dapat disimpulkan

bahwa semakin tinggi tingkat konsentrasi yang digunakan maka akan semakin tinggi efektivitas ekstrak bawang putih (allium sativum) sebagai insektisida terhadap kutu rambut (pediculus capitis).

\section{KESIMPULAN}

Dari hasil penelitian yang dilakukan didapatkan kesimpulan yaitu ekstrak bawang putih efektif sebagai insektisida terhadap kutu rambut. Pada konsentrasi $4 \%$ membutuhkan waktu bunuh selama 0,4450 jam, dengan konsentrasi 6\% membutuhkan waktu bunuh 0,1380 jam, dan pada konsentrasi $8 \%$ membutuhkan waktu bunuh 0,0630 jam. Dimana semakin tinggi konsentrasi ekstrak bawang putih maka semakin efektif sebagai insektisida terhadap kutu rambut sehingga ekstrak bawang putih dengan konsetrasi $8 \%$ lebih efektif dari pada ekstrak bawang putih dengan konsentrasi $4 \%$ dan $6 \%$.

\section{SARAN}

Berdasarkan kesimpulan diatas maka peneliti memberikan saran untuk melakukan penelitian lebih lanjut untuk menentukan konsentrasi yang tepat apabila akan diaplikasikan pada kulit kepala, melakukan penelitian lebih lanjut unutk mengetahui bentuk sediaan yang paling baik untuk insektisida, dan melakukan penelitian lebih lanjut dengan konsentrasi lebih tinggi untuk mengetahui konsentrasi ekstrak bawang putih yang lebih efektif.

\section{DAFTAR RUJUKAN}

Alatas, S. 2013. Hubungan Tingkat Pengetahuan Mengenai Pedikulosis Kapitis Dengan Karakteristik Demografi Santri Pesantren X Jakarta Timur. Jurnal Karya Ilmiah, 1(1):54. Ansyah, A. 2013. Hubungan Personal

Hygiene Dengan Angka Kejadian Pediculosis Capitis Pada Santri Putri Pondok Pesantren Modern Islam Assalaam

Surakarta.Skripsi.Surakarta: Universitas Muhammdadiyah Surakarta.

Asmaliyah. Wati, E. 2010. Pengenalan Tumbuhan Penghasil Pestisida Nabati Dan Pemanfaatannya Secara Tradisional. Palembang: Kementrian Perhutanan.

Burton, R. 2013. Efek Infusa Bawang Putih (Allium Sativum) Sebagai Lavarsida Nyamuk Culex sp Serta Penentuan LD-50. Skripsi. Bandung: Universitas Kristen Maranatha.

Fadilah, H. 2015. Perbedaan Metode Ceramah Dan Leaflet Terhadap Skor Pengetahuan Santriwati Tentang Pedikulosis Kapitis Di

Pondok Pesantren AlMimbar Sambongdukuh Jombang. Skripsi. Jakarta: Universitas Negeri Syarif hidayatullah Jakarta.

Hanani, S. 2013. Uji Efektivitas Larutan Bawang Putih Sebagai Insektisida Nabati Untuk Membunuh Larva Nyamuk Aedes Aegyti. Skripsi. Gorontalo: Universitas Negeri gorontalo.

Hernawan, U. 2013. Senyawa Organosulfur Bawang Putih (Allium Sativum) Dan Aktivitas Biologi. Jurnal Biofarmasi, 1(2):65-67 
Hudayya, A. 2012. Pengelompokan Pestisida Berdasarkan Cara Kerjanya (Mode Of action). Lembang: Yayasan Bina Tani sejahtera

Kepmenkes RI. 2012. Pedoman Penggunaan Insektisida (Peptisida). Jakarta:

Kementrian Kesehatan.

Khairani, A. 2014. Bawang Putih Raja

Tanaman

Kedokteran.

Surabaya: Alfasyam

Publishing.

Muta'ali, R. 2015. Pengaruh Ekstraksi Daun Beluntas (Plucea Indica) Terhadap Mortalitas Dan Perkembangan Larva Spodoptera Litura F. Jurnal Sains Dan Seni, 4 (02):56-57.

Nindia, Y. 2016. Prevalensi Infestasi

Kutu Kepala (Pediculus Humanus Capitis) Dan

Faktor Resiko Penularannya Pada Anak Sekolah Dasar Di Kota Sabang Provinsi Aceh. Skripsi. Bogor: Institusi Pertanian Bogor.

Nisma. Utarmi, N. 2011. Isolasi Senyawa Flavonoid Dari

Ekstrak Air Serbuk Daun Gamal (Gliricidia Maculata) Dan Uji Toksisitasnya Terhadap Hama Kutu Putih Pepaya (Paracoccus Marginatus). Skripsi. Bandar Lampung: Universitas lampung.

Public School NSW. 2013. Pilihan Pengobatan Kutu Kepala. Nitbusters Goverment.

Rachman, A. 2015. Isolasi Dan Identifikasi Senyawa Saponin
Ekstrak Metanol Daun

Binahong (Anredera cordifolia (Ten.) Steenis). Chem Info, 1(1):1.

Rumampuk, M. 2014. Peranan Kebersihan Kulit Kepala Dan Rambut Dalam Penanggulangan

Epidemiologi Pediculus Humanus Capitis. Jurnal Ners, 9(1):36.

Sukma, D. 2016. Sehat Tanpa Obat Dengan Bawang Merah Dan Bawang Putih. Yogyakarta: Rapha Publishing

Susilo, F. 2013. Peningkatan Efektivitas Pada Proses Pembelajaran.Skripsi.Surabaya: Universitas Negeri Surabaya.

Tigauw, S. 2015. Eektivitas Ekstrak Bawang Putih Dan Tembakau Terhadap Kutu Daub (Myzus percisae Sulz.) Pada Tanaman Cabai.Eugenia, 21 (03):6.

Trishadi, R. 2016. Pestisida Nabati Ramah Lingkungan Untuk Mengendalikan Hama Dan

Penyakit Tanaman. Probolinggo: Dinas Perkebunan Dan Perhutanan.

Yenie, E. 2013. Pembuatan Pestisida Organik Mengunakan Metode Ekstraksi Dari Sampah Daun Pepaya Dan Umbi Bawang Putih. Jurnal Teknik Lingkungan, 10 (1):47.

Yuniastuti, K. 2006. Ekstraksi Dan Identifikasi komponen Sulfida Pada Bawang Putih (Allium Sativum). Tesis. Semarang: Universitas Negeri Semarang. 